\title{
Matching Supply and Demand for Scarce Skills and Career Guidance in the Post-Apartheid Setting
}

\author{
IM Ntshoe \\ Central University of Technology, Free State, Private Bag X 20539, Bloemfontein. \\ intshoe@cut.ac.za \\ JM Selesho \\ Vaal University of Technology, Bag X 21, Vanderbijpark. \\ jacobs@vut.ac.za
}

\section{Doi:10.5901/mjss.2013.v4n3p45}

\begin{abstract}
This article is on forecasting and matching skills supplied by education institutions, with the demands of employers using South Africa after the first democratic election of 1994. We do this by examining forecasting and matching; guidance and counseling; subject choice and early specialisation at school and tertiary levels. We argue that forecasting and matching is generally a weak planning strategy because the short-term demands of employers and the time-lag it takes to produce a graduate in a particular field. This strategy is especially limited in a country with first and second tier economies, and where the schooling system still reflects the geopolitical experiences of the past. We further argue that the provision of scares skills is undermined by the political imperatives to increase the pass rate by lowering the pass percentage. It is argued that ill-advised subject choice, early specialisation and guidance and counselling programmes in a watered-down curriculum are not compelling, but likely to undermine the intention of producing students qualified in science, engineering and technology.
\end{abstract}

Keywords: Forecast and matching, quality education, subject choice, early specialisation, guidance and counselling

\section{Introduction}

Fluctuations between shortages of skills in certain fields and an oversupply in others reflect the long-standing nervousness on the supply side involving skills supplied by higher education institutions on the one hand, and the demand side involving skills required by employers and the general requirements and expectations of the markets, on the other. The unsteadiness between the supply by education institutions and the demands by employers is becoming a concern because of the burgeoning demand for higher education, a corresponding increase in graduate unemployment, as well the changing nature of employment in the new economy. Two issues that form the thrust of this article are first, the extent to which tertiary institutions should align their offerings and programmes to the narrow and short-lived demands of employers or whether students should rather be provided with disciplinary content, general principles and knowledge that can be applied in diverse contexts and times. The second issue relates to the quality of school education, the choice of subjects by students, the changing nature of employment, as well as a stronger focus on guidance and counselling to address the acute shortage of skills in some areas and an oversupply in others.

This article begins by discussing theoretical and conceptual discussions on forecasting supply and demand, together with the challenges and critiques of these that draw on the economics of education in the 1960s and 1970s with their related policy responses. It then proceeds with a discussion of quality education and subject choice in increasing the number of students with good pass rates in mathematics, the physical sciences and technology using the 2009/2011 pass rate figures in these subjects in South Africa. The next section is on the connection between matching and guidance and conselling highlighting the limitations inherent in this connection. Lastly, the article presents discussions and implications for theory and practice and thereafter, draws conclusions. Statistical data for this article were collected from primary and secondary sources including policies and legislations, the relevant literature, professional councils and from research units on the topic. Mark Blaug's (1976) theoretical and conceptual framework has been adopted to scaffold discussions in the paper. 


\section{Forecasting Shortages, Surpluses and Policy Responses}

Despite the changing nature of employment and skills in the new economy, the conventional manpower forecast of the demand and supply approach and the corresponding forecasts in educational policy and planning in the 1960s and 1970s seem to be increasingly shaping policy, albeit in a diluted form (Organisation of Economic and Corporation Development (OECD), 1996). However, conventional manpower forecasts seem to have been replaced by matching expectations in the labour market with what institutions should produce. Matching however, differs only in degree, but not in kind from manpower forecasts because its underpinning assumptions still resonate strongly with the basic tenets of forecasting demands and the supply of skills in the 1960s and 1970s (see Bombach 1965; Carter 1965; Jolly 1964).

The nuances between manpower forecast, projections and predictions, as well as matching in the discussions about shortages in certain categories of skills and the oversupply of others needs to be underscored. According to Blaug (1976), manpower forecasting is an attempt to predict the future demand for educated manpower, but only in the special sense of demand. Forecasts refer to predictions that depend on the achievement of definite growth targets and seek to predict what would happen if economic growth was deliberately manipulated by the government. Projections, on the other hand, relate more to the predictions of the outcomes of spontaneous forces. For example, what would happen in the normal course of events in an unplanned economy? (Blaug 1976). Conventional manpower forecast previously used in conjunction with projections of demands-for-places asserted that it was possible to tell education planners the number of scientists, engineers, technicians which should be supplied in five to ten years' time (Blaug 1976, 184).

Matching assumes that institutions of education need to align their curricular, programmes and offerings with the expectations and requirements of employers or markets if they wish to remain relevant. The emerging trend therefore points to the tipping of the scales in favour of the demand side of the supply-demand side tension.

Closely related to matching is the belief that the shortages of skills in certain categories and surpluses in others could be attributed to the lack of career counselling for students both at school level and those entering tertiary institutions. The rationale behind this principle is that once students have been provided with knowledge about career opportunities in certain job categories, they will automatically make informed choices in those fields and consequently, enrol for fields required by the markets. It is also often asserted that adequate guidance and counselling can assist in dealing with supply and demand, or matching skills from the supply and demand sides. The typical use of what seems to be an orthodox supply and demand (matching) and its relationship to education policy is South Africa is discussed next.

Woolard et al. (2003, p.468-472) used this approach to forecast the demand and supply in certain categories of occupations in 2008 and arrived at the following conclusions.: First, A strong demand for engineers and natural scientists; ii) High demand in the IT professions; iii)Growth in the number of teachers and nurses that would depend on the government's fiscal stance, which has a certain degree of ambiguity; and, iv). Demand for managers that was expected to be small as firms remain small and strive to become globally competitive, but demand for managers with financial and people skills was expected to be stronger.

Daniels similarly forecasted shortages of middle- and senior managers in 2006 arguing that a skills shortage existed within all industry types, e.g. mine managers or shaft managers in the mining industry, foremen and managing engineers in the manufacturing industry and general business managers in the services industry. The author attributed the shortages of technical skills to a declining enrolment in the engineering sciences at tertiary institutions during the 1990s, while graduation in 'softer' non-technical fields of study had been on the rise (Daniels 2006).

Arguing along similar lines, the South African Institute for Chartered Accountants (SAICA) (2008) made three kinds of projected demands for various occupations. First, SAICA (2008) projected the total number of positions in the sector to increase from 305000 in 2007 to 401000 in 2018, 460000 in an optimistic scenario and 349000 in a pessimistic one. Second, SAICA further projected that under baseline scenario one, the total number of positions to be created in 2008 was 6829 and this would increase to 9933 in 2018. In scenario two, the positions in 2008 would have been 9986 and would increase to 17466 by 2018. The third scenario is that the new positions would have increased from 2592 in 2008 to 4076 in 2018 (SAICA 2008).

Explicitly supports forecasts shortages in the science- and economic-based fields and especially in information technology, engineering, technological and technical occupations, economic and financial occupations, accountancy and related areas (DoE 2001).

In an apparent endorsement of matching, The National Plan on Higher Education (The Plan) Plan proposes a shift of balance in enrolments over the next five to ten years between the humanities, business and commerce and science, engineering and technology from the current ratios of 49\%: 26\%: 25\% to 40\%: $30 \%$ : 30\%respectively (DoE 2001). 
The Ministry however, remains mindful that the school system is not at present, able to produce large numbers of matriculants who have the required proficiency in mathematics, which is generally a prerequisite for entry into these programmes (DoE 2001). The former deputy president of the Republic of South Africa spoke about the negative impact of the lack of matching in the previous administration, arguing that the phenomenon of unemployed graduates, who are without abilities to self-employ and self-determine, after spending three to four years of post secondary education, is an indication of the problems in our education at a tertiary level (Mlambo-Ngcuka 2006). According to Mlambo-Ngcuka:

The curriculum developers are not paying enough attention to issues of relevance and ensuring that we all pay attention to the skills and competencies learners require when they come out of higher education... we need a skills revolution in the curriculum of tertiary education. (Mlambo-Ngcuka 2006)

In seeming support of matching, Higher Education South Africa (HESA) commissioned a pilot study to examine the expectations of employers and to evaluate the quality of graduates produced by higher education institutions (Griesel \& Packer 2009). HESA hoped that the outcomes of the study would provide useful data to inform debate and engagement with industry and furthermore, to establish an empirical benchmark against which to conduct periodic future reviews in terms of what employers expect from higher education institutions (Griesel \& Packer 2009). In this study therefore, HESA was mindful of the seeming gap between the outcomes of higher education (in terms of quality, type and quantity of graduates), and the needs of the economy (Yorke 2006, 10; Harvey 2001).

Similarly, the Minister of Higher Education and Training, Nzimande noted that industries such as engineering, life and physical sciences, animal and human health and teacher education were experiencing a skills shortage (Grobbelaar 2011p.9). The Minister observed that South African universities produced only 8427 engineering graduates in 2009 and that 1500 graduates would be needed in engineering fields by 2014 (Grobbelaar 2011, p.9). Minister Nzimande contends that the government needs more detailed information about the shortage of skilled university graduates before it can address the problem (du Plessis 2009). The ministry argues that 'programmes' offered by Sector Education and Training Authorities (SETAs) require input from the labour market, as well as vehicles for matching potential learners to opportunities.

\section{Quality of Education and Subject Choice}

Forecasting and matching supply planning policy with the demand for skills required by employers is inextricably linked to the quality of education and subject choice at school level which, in turn, determine qualifications and subject choices at university levels.

Consequently, the issue of, in what fields students qualify to enrol at tertiary level is entirely dependent on the quality of education, curricula and subject choice, and the quality of students completing matric and entering tertiary institutions. It is therefore both the quantity and quality of students completing matric with adequate knowledge of mathematics and the physical sciences that seem to be the major source of the problem of a shortage of scarce skills, thus leading to a skills deficit.

Accordingly, the current outcry about the shortage of skills in some categories of occupations and professions and the oversupply in others can be attributed to a number of factors. For example, research has observed that various firms have pointed out that they believe the poor quality of education at school level, especially in mathematics and science is to blame for the low enrolment numbers in key study areas, as well as the poor academic performance of students in general (Daniels 2006). Daniels further observed a perception among employers that current educational subsidies are causing institutions to focus on enrolling large numbers of students, rather than on the quality of education (2006).

In writing about the need to increase the pool of graduates in the area of math sans science, Jawitz et al. (2000) argue that the country should increase the throughput of engineering professionals (particularly students from the poorer sections of society), previously excluded from participation in the higher education sector in South Africa. To accomplish this, it is necessary to improve mathematics and physical science teaching in schools and encourage more school learners to consider careers in engineering (Jawitz et al., 2000).

Du Toit and Roodt (2009) also maintain that while there have been talks for universities to increase the size of their engineering faculties in South Africa, the potential pool of candidates for higher education institutions has not increased sufficiently, especially in respect of those with HG (higher grade) passes in mathematics and the physical sciences.

The negative impact of poor quality teaching and the choice of subjects on shortages in the engineering profession was articulated by Du Toit and Roodt as follows: i)The low number of matriculants who pass Grade 12 with higher grade (mathematics and physical science) and thus qualify to pursue engineering studies; ii) The quality of mathematics and 
science knowledge that these students bring with them to the university context; iii) The relative attractiveness of other professional study programmes such as medicine and commerce, which compete for students from the same limited pool of matriculants; and, iv) Low output rates for higher education (2009).

When addressing the press conference on the 2010 results, the Minister of Basic Education expressed some optimism of increasing the pool of students who can take mathematics and the physical sciences at tertiary level. The Minister had this to say:

\begin{abstract}
I am particularly pleased with the increase by 1,4\% and $11 \%$ in the pass rate in mathematics and physical science, respectively. The number of learners who passed Accounting has also increased by $1.3 \%$ compared to the past two years. These results have shown that through dedication, hard work and commitment, the basic education system will improve the levels of learner attainment and achieve the objectives of schooling by 2025. (Motshekga 2010, p.8)
\end{abstract}

The Minister further pointed out that in 2010 more learners registered for mathematics (maths) (296 659) than for mathematical literacy (284 309) compared to the 2009 cohorts. However, the expressed optimism about increased number of students who registered for maths is misleading because, far fewer pupils ended up with a maths pass (124 749) than a mathematical literacy pass (241 576). This means that the maths pass rate has stayed the same for 2009 and 2010 at 46 percent, but the mathematical literacy rate dropped from 79 to 75 percent (Serrao et al., 2010).

Table 1 shows that the number of matriculants who wrote and passed mathematics in the period 2006 to 2009 varied from 33, $8 \%$ in 2006 to $45,9 \%$ in 2009 , with a notable decline from $47.3 \%$ in 2010 to $46.3 \%$ in 2011 . The percentage of matriculants who wrote and passed science in the period 2006 to 2009 decreased from $67,39 \%$ in 2006 to $28,6 \%$ in 2009. A significantly low number of matriculants wrote and passed maths and science in the period 2006 to 2009 (Solidarity Research Institute 2010; South African Institute of Race Relations (SAIRR), 2009/10).

Table 1. The National Senior Certificate examination results for Mathematics, Mathematical Literacy and Physical Sciences in 2009 to 2011

\begin{tabular}{|c|c|c|c|c|c|c|c|c|c|}
\hline & \multicolumn{3}{|c|}{2009} & \multicolumn{3}{|c|}{2010} & \multicolumn{3}{c|}{2011} \\
\hline & $\begin{array}{c}\text { Total } \\
\text { wrote }\end{array}$ & $\begin{array}{c}\text { Passed } \\
\text { at 30\% } \\
\text { or more }\end{array}$ & $\begin{array}{c}\text { \%Passe } \\
\text { d at 30\% } \\
\text { or more }\end{array}$ & $\begin{array}{c}\text { Total } \\
\text { wrote }\end{array}$ & $\begin{array}{c}\text { Passed } \\
\text { at 30\% } \\
\text { or more }\end{array}$ & $\begin{array}{c}\% \text { Passed } \\
\text { at 30\% or } \\
\text { more }\end{array}$ & $\begin{array}{c}\text { Total } \\
\text { wrote }\end{array}$ & $\begin{array}{c}\text { Passed } \\
\text { at 30\% } \\
\text { or more }\end{array}$ & $\begin{array}{c}\% \text { Passed } \\
\text { at 30\% or } \\
\text { more }\end{array}$ \\
\hline $\begin{array}{c}\text { Mathematical } \\
\text { Literacy }\end{array}$ & 227,677 & 207,326 & $74.7 \%$ & 280,836 & 241,576 & $86.0 \%$ & $\begin{array}{c}275,38 \\
0\end{array}$ & 236,548 & $85.9 \%$ \\
\hline Mathematics & 290,407 & 133,505 & $46 \%$ & 263,034 & 124,749 & $47.4 \%$ & $\begin{array}{c}224,63 \\
5\end{array}$ & 104,033 & $46.3 \%$ \\
\hline $\begin{array}{c}\text { Physical } \\
\text { Science }\end{array}$ & 439,038 & 201,179 & $28.6 \%$ & 205,364 & 98,260 & $47.8 \%$ & $\begin{array}{c}104 \\
033\end{array}$ & 96441 & $53.4 \%$ \\
\hline
\end{tabular}

Source: Department of Education Statistics in South Africa 2009. Department of Basic Education 2010

In 2011, a total of 104033 candidates passed mathematics while 96441 candidates achieved a pass in physical science. The pass rate for mathematics was $46.3 \%$ in 2011, a decline from 47.4\% in 2010. In mathematical literacy 236548 learners passed in 2011, compared to 241576 in 2010 (Motshekga 2012). Accordingly, the total number of matric candidates who passed mathematics dropped from 124,749 in 2010 to 104,033 in 2011. This is a decline of 20,716 or 17\%. This continues a trend seen in 2010 when the number of passes dropped from 133,505 in 2009 to 124,749 in 2010. The maths pass-rate declined to $46.3 \%$, but at only 104,033 passes in 2011, the reality is that only about 1 in 5 of all matriculants achieved a pass in maths.

Accordingly, just $21 \%$ of all those who wrote matric got above $30 \%$ for mathematics. When one considers that mathematics is a crucial skill and a gateway to science, medicine, commerce, engineering and many other vital parts of the economy, this trend is extremely worrying. Maths literacy, whilst useful, is not a substitute (Hodgson 2012).

Similarly, statistics in Table 2 show the number of students who obtained symbols A-C in mathematics and science for 2007 to 2009 . 
Table 2. Symbols in Science and Mathematics: 2006-2009

\begin{tabular}{|c|c|c|c|c|}
\hline \multicolumn{5}{|c|}{ Grade 12s with symbols $A$ to $C$ in Mathematics } \\
\hline 2006 & 2007 & 2008 & 2009 & \\
\hline 37809 & 40652 & 14578 & 31743 & $2,20 \%$ \\
\hline \multicolumn{5}{|c|}{ Grade 12 with symbols $\mathrm{A}$ to $\mathrm{C}$ in Science } \\
\hline 2006 & 2007 & 2008 & 2009 & \\
\hline 15401 & 40285 & 17162 & 10258 & $0,71 \%$ \\
\hline \multicolumn{5}{|c|}{ Grade 12 s with a C symbol in Mathematics } \\
\hline 2006 & 2007 & 2008 & 2009 & \\
\hline 10638 & 11495 & 12482 & 8710 & $0,07 \%$ \\
\hline 2006 & 2007 & 2008 & 2009 & \\
\hline 3385 & 2846 & 2516 & 987 & $0,07 \%$ \\
\hline
\end{tabular}

Source: Race Relations Report 2010

The National Senior Certificate examination results for mathematics, mathematical literacy and physical science in 2009 and 2011 discussed tell a story about the nature of the school curriculum as a factor influencing the provision of scarce skills.

The reality is that progress in terms of the pass rates of matric students in mathematics and science from 2006 to 2011, has been conservative and in fact, has been on a sliding scale. Statistics reveal that the number of matriculants who qualify for admission to fields of study such as engineering, life sciences and medicine remains bleak. The implication of this trend is therefore that even with the most reliable forecast the schooling system will not be able to meet the demands for skills in these areas.

Tables 1 and 2 reveal that the pool of school leavers who are suitably qualified to enter engineering programmes is stagnating, if not shrinking and of these, only a small subset are choosing to study engineering. This situation is not improving, despite the unprecedented increase in government resources to students in the form of bursaries and loans, especially in the area of Science Engineering and Technology (SET). When this group enters higher education institutions, many of them experience difficulties due, at least in part, to the poor school backgrounds that some of them have come from (Jawitz et al., 2008). Du Toit and Roodt (2009) concur that despite the good intentions of the policy of introducing maths literacy this has not assisted with the creation of a pool of potential candidates for higher education institutions who have higher grade passes in maths and physics.

Table 3, on the other hand, provides a conservative percentage increase in the proportion of graduates in science, engineering and technology. The table shows that it will take the country fifteen years to increase the number of graduates in SET by only 1\%. It is therefore indicates that there is conservative growth in these subjects, despite the increased government allocation of resources in these fields.

Table 3. Proportion of graduates in science, engineering, and technology (SET) in higher education, 1994-2007

\begin{tabular}{|c|c|}
\hline Year & Proportion \\
\hline 1994 & $27.8 \%$ \\
\hline 1995 & $25.0 \%$ \\
\hline 1996 & $25.2 \%$ \\
\hline 1997 & $26.0 \%$ \\
\hline 1998 & $26.0 \%$ \\
\hline 1999 & $25.2 \%$ \\
\hline 2000 & $26.2 \%$ \\
\hline 2001 & $25.1 \%$ \\
\hline 2002 & $26.8 \%$ \\
\hline 2003 & $28.0 \%$ \\
\hline 2004 & $26.8 \%$ \\
\hline 2005 & $27.9 \%$ \\
\hline 2006 & $28.5 \%$ \\
\hline 2007 & $28.8 \%$ \\
\hline
\end{tabular}

Source: Department of Education, Trends in Education Macro Indicators Summary Report 2009, p.38 
Regarding career choice, there have apparently, been insignificant changes in the number of students taking up engineering studies at universities in comparison with the dramatic increase in those studying towards an engineering qualification at a university of technology (Du Toit \& Roodt 2009). Accordingly, there has been a marginal increase in the absolute number of engineers graduating from universities as technologists and technicians from universities of technology over the 1996-2005 period.

Lawless (2005) observes that there has been only a marginal increase in the absolute number of engineers graduating from South African universities over the past 20 years, although there is a significant increase in the number of other engineering professionals qualifying from universities of technology (formerly technikons) over the same period. At the same time, there has however, been a fairly dramatic shift in the demographic composition of the student bodies at these institutions.

Jawitz et al. observe that at universities of technology there has been a dramatic increase in those studying towards engineering qualifications (Lawless 2005), at least in part, due to the introduction of the Bachelor of Technology (B.Tech)degree but the throughput rates from the engineering programmes at these institutions seem to be relatively low (Jawitz et al., 2008).

With regard to the school context, the actual quality of mathematics and physical science teaching appears to have changed little since the early 1990s, despite a unification of the education system and a number of curriculum changes (Lawless 2005). Furthermore, there is, according to Lawless, a widening disparity between schools that were well funded for certain sections of the South African population (which have become officially desegregated) and those that were designated for the poorer sections of society and were poorly funded before the democratic changes of 1994 in South Africa (and continue to serve the poorest sectors of the population, by far the largest part of the school-going population).

\section{Matching and Guidance and Counselling}

A growing trend is emerging that attributes the lack of a match between the supply side with the demand side to ineffective student guidance and counselling both at school level and when students apply for places at tertiary institutions.

The clarion call for effective career guidance and counselling to assist students in making wise choices of careers in higher education is shared by the ministry of higher education and training, professional bodies and academics (Grobbellaar 2011).

Mabena (1997, p.7) similarly attributed the shortage of African accountants to the lack of knowledge on career guidance and knowledge in the careers related to the accounting profession by students from the African community in South Africa. In this study, $84 \%$ of the respondents said that the main reason for the small number of Africans in the profession was a lack of career guidance in schools (Mabena 1997, p.7). Sadler concurs that career guidance counsellors have an influence as far as students' early career decisions are concerned. She noted SAICA's concern that teachers do not encourage their best students to study accountancy, and that was the reason for the Institute forming a teachers' enrichment project (Sadler undated, 12).

Table 4 reflects the responses of students on why there has been a small number of African Chartered Accountants in South Africa. The table suggests that a lack of career guidance tops the list of reasons why black students are not keen to make Chartered Accountancy (CA) a career. A lack of career guidance is followed by a lack of knowledge about the profession, with a lack of training ranking lowest.

Table 4. Responses on why the number of black students remains small in Accounting

\begin{tabular}{|l|c|}
\hline Lack of career guidance & $84,06 \%$ \\
\hline Lack of knowledge about the profession at school & $71,01 \%$ \\
\hline Lack of role models & $59,42 \%$ \\
\hline Lack of exposure and bursary problems & $56,53 \%$ \\
\hline Lack of funding and bursary problems & $49,28 \%$ \\
\hline Poor academic standard at school & $47,83 \%$ \\
\hline Unable to get articles & $40,58 \%$ \\
\hline Lack of teachers in commerce and maths & $37,68 \%$ \\
\hline Racial discrimination & $34,78 \%$ \\
\hline Not encouraged to take accountancy at school & $30,43 \%$ \\
\hline Employers prejudiced & $11,59 \%$ \\
\hline
\end{tabular}


Source: Sadler undated

\begin{tabular}{|l|l|}
\hline Accountancy considered to be a white occupation & 10,14 \\
\hline Inability in the community & 10,14 \\
\hline Length of training & $7.25 \%$ \\
\hline
\end{tabular}

Similarly, Jawitz et al. (2000) argue that the lack of guidance and counselling is one of the contributors to why female African students in South Africa are not taking engineering at university level and as a career.

The general agreement seems to be that learners need to be guided prior to enrolment at university on both the best match of their interests and abilities with occupational requirements, as well as on their best prospects for employment and decent remuneration. The ministry of higher education has added its voice to the chorus about the importance of guidance and counselling.

Du Toit and Roodt (2005) argue that the underlying reasons behind career choice by students are complex, in that it is not the choice of the individual alone, but of his/her family as well. Policies relating to career guidance in this regard would refer only to the development or improvement of comprehensive information systems that could inform people of all the available possibilities for upgrading their skills and qualifications. Career guidance policy should primarily be directed towards the development of services and systems that can enhance the notion of lifelong learning which has become a reality in the world-of-work over the past few years. This means that services are not only needed at one specific point in time, but should be made available to people across their work-life span whenever they need them. Career guidance policy should furthermore, strive to augment labour market efficiency. People should have access to information about the labour market in order to make informed decisions and to be absorbed into the labour market in positions where they can apply their skills effectively. Finally, career guidance policy should also aim to improve social equity, one of the major problems many developing countries face. Everyone should have access to information and services according to his/her specific needs throughout his/her work-lifespan. If career guidance policies are planned and developed within this framework, the value of these policies as a developmental instrument will certainly increase. In developing countries change can be very rapid and often profound. Consequently, there is a greater need to keep career and employment information flowing at all levels and across all sections of the community (du Toit 2005).

\section{Discussions and Implications for Theory and Practice}

The conventional manpower supply-and-demand economic model that characterised educational planning policies in the 1960s and 1970s seems to have made a comeback in the debates about a shortage of skills in certain areas and the oversupply in others in South Africa. While the conventional models gave prominence to forecasting and predictions, these models have evolved overtime into matching the supply-demand side by higher education institutions, with the demand side of the market and employers. Accordingly, a matching model has become generally embraced globally and in South Africa in educational planning, as well as in the discussions on the supply and demand sides in relation to the challenge of the shortage of skills in certain areas and the oversupply in others. Closely related to the claim that higher education institutions should match their career offerings with the expectations and requirements of the market, is the emerging argument that matching is currently weakened by a lack of adequate career guidance and counselling to students about skills needed, and which will be needed by employers in future. It is thus often claimed that, armed with adequate information about skills demanded by employers and the available places in the various professions, students will be able to choose wisely when they have sufficient knowledge of areas where there are shortages and where there are surpluses.

The remaining part of this paper deals with the critical discussions on the ongoing use of supply and demand, matching, the role of career guidance and counselling, subject choice and the quality of education in the changing nature of employment and the new economy in South Africa.

Matching is still a dominant policy mode on how to provide the necessary skills to employers, as well as making students employable (cf Daniels 2006; SAICA 2008; DoE 2001; Griesel \& Packer 2009; Grobbelaar 2011, p.9).

Similarly, Business South Africa (BUSA) and other commentators endorse this view that while university graduates are well trained it could take years before they acquire the necessary skills needed to navigate the business environment (du Plessis 2009).

Despite inaccuracies in both the supply and demand models and their modified versions, the matching model identified by previous studies and commentators remain as controversial as they were thirty years ago, primarily because of the changing nature of employment in the new economy. 
In one of his seminal works Blaug, on whose framework much of what is discussed below draws on, provides a critical assessment of conventional manpower forecasting and came to the conclusion that manpower which forecasts whatever form it takes, remains inherently problematic (Blaug 1976; Chapt.5). Blaug attributes this to imperfections in the market or market elasticity, the lag in market effect, together with market failures that occur from time to time (1976). The reservations expressed by Blaug though rarely examined, apply equally closely to the matching approach generally embraced in South Africa.

Blaug correctly points out that one of the problems of manpower forecasting, and this can also be said of matching, is the length of time it takes to produce professions, so much so, that by the time these people are qualified after five to seven years, the demands in the markets have changed threefold (Blaug 1976, p.138). Blaug argues that manpower forecasting is particularly unreliable where students specialise early on in their studies, even if they are provided with the best vocational guidance and counselling. He further argues that the situation is lightly to be better where students are allowed to choose their subjects once they have gained admission to a university (ibid, p.215). Drawing from Blaug's work therefore, I argue that the current confidence in student guidance and counselling, coupled with early specialistion in South African education, is unlikely to assist in increasing the pool of students who can take mathematics, science, engineering and technology (MSET) at university level

In the light of the arguments above, the current trend in South Africa to attribute mismatches between what schools and higher learning institutions produce, and what employers and the market expect is simplistic and unlikely to improve practice. The belief is one-dimensional because specialisation in the early stages of schooling limits students' choices for what they can register at tertiary institutions. For example, students in South Africa have a choice of whether they wish to take science, accounting, mathematics, or mathematical literacy and physics in their last three years of high school. Having a choice, students naturally do not often enroll for these fields.

Furthermore, Blaug's suspicion as to whether subject choice would improve if students were provided with adequate information form guidance and counseling about the demands of a particular profession is a key consideration for policy making. Blaug further advises that this information would be of little value as "students are in the same position as oligopolists who cannot decide what price to charge without knowledge of the prices that rivals will be charging" (Blaug 1976, p.164). It is therefore not enough in terms of this dictum to tell students about the demands in certain professions; for example, in engineering or accountancy, without also telling them about the probable supply in these professions. In addition to this information therefore, students need to be provided with the knowledge of both, because if the shortage is focused upon, students need not worry about their aptitude in a particular field as they will find employment in any case. If however, the forecast suggests that there will be a buyers' market (where institutions overproduce students for a particular profession) then students need to pay stricter attention to their own occupational aptitudes (Blaug 1976, p.164).

In addition to the negative effects of early specialisation by students in South Africa is the introduction of mathematical literacy. It appears from a policy perspective that mathematical literacy was introduced to address a national outcry that insufficient learners, especially black students, do not have maths at matric level and that this tends to undermine the broadening of access of these communities to fields that require mathematics. This reality is that the introduction of maths literacy has not contributed positively to broadening the pool of students with respectable marks in mathematics and the physical sciences so that they may enrol for these fields and address the scarcity in them. In fact, the majority of students who pass maths literacy do not qualify to enrol for the very areas where the scarcity of skills is acute including engineering, physical science and accounting, at university level. However, as the tables above suggest, maths literacy has instead worsened the situation of students who take this subject at matric level because it is not recognised by universities as being on the same level as mathematics. Consequently, while maths literacy might have increased the matric pass rate, this maths literacy seems to reinforce the inequities of outcomes in at least two ways. First, in response to the Ministry of Education, there is the pressure for schools to improve their matric pass rate and most students are encouraged to take mathematical literacy in order to increase their pass rate. Second, it is the African pupils admitted in formally privileged schools that are now open to all population groups that are usually encouraged to choose mathematical literacy to increase the pass rates at these schools.

Equally counterproductive, in trying to broaden the pool of students with decent marks in mathematics and physical science is the seeming lowering of the pass percentage, where students are expected to obtain only $30 \%$ to pass and $40 \%$ as a good pass. The reality is that, the $30 \%$ and $40 \%$ pass in mathematics and physical science serve only to create unrealistic expectations that students can enrol for qualifications and programmes that require a pass in maths, science engineering, accounting and medicine at university level, when in fact, this is not the case.

This and other factors including poor subject choice and early specialisation at school level, then subsequently at undergraduate level, explain the perennial problem of shortage of places for students at university at the beginning of 
each year. In fact, the stark reality is that mathematical literacy seems to undermine the gains made over the last seventeen years to increase the number of blacks in science, engineering and technology (SET).

Thus, the destiny of most students, especially those who come from poor communities and schools in townships, where most of them are staffed with unqualified teachers, have weak school governing and management structures, is decided long before they complete their high school education. This trend explains why the pool of matriculants qualified to enrol for mathematics, accountancy and physics remains small, despite substantial increases in resources allocated to education by various means including, government bursaries, and a non-fee paying policy and increased input into the National Student Financial Aid Scheme of South Africa (NSFAS) for tertiary students.

\section{Conclusion}

In this article, we examined the challenges of the fluctuations between the shortage of skills in certain categories and the oversupply in others in the context of a long-standing uneasiness between the supply from higher education institutions, and the demand from employers in South Africa. We argue firstly, that while the conventional model of manpower forecast of the 1960s and 1970s showed some weaknesses, its modified version (matching) continues to shape policy and practice on the supply of educational services by tertiary institutions and the skills demanded by employers. We further argue that the term 'matching', generally embraced as a policy of educational planning, differs in degree but not in kind from the traditional manpower forecasts and predictions of certain skills required by employers in the 1960s and 1970s. Accordingly, matching we argue, has similar intrinsic inadequacies to those of the traditional manpower forecast and that policy makers need to be wary about the extent to which matching is a reliable strategy for closing the gap between the supply and demand skills needed by employers, especially in the current changing nature of employment and the new economy in South Africa and elsewhere. We propose that while higher education institutions should listen with one ear to the employers, they should take note with the other of the provision of principles, concepts and knowledge about skills demanded by the different business fields, because the requirements of employers are short-lived and change rapidly.

We also explored the inherent deficiencies of early specialisation at high school and at undergraduate level as is the case in South Africa as it (specialisation) militates against efforts of broadening the pool of students who qualify to enrol for occupational careers in engineering, accounting and mathematics. Additionally, we argue that learners at school level and the most able students at undergraduate level should be exposed to pure maths, physics and accounting and be allowed to specialise only at postgraduate level. There seems to be no compelling explanation why all students cannot do maths, physics and accountancy at school level and at university level, unless it is assumed that South African children have no inherent capability of doing these subjects. Rather than lowering the pass rate therefore, pupils in schools should all be required to take mathematics and physical science and teachers responsible for these subjects need to be retrained in the content, disciplinary knowledge in these subjects (the what), as opposed to the how, which seems to dominate teacher training following the introduction of outcomes-based education and its variations.

We also question the motive for introducing mathematical literacy in South African schools, arguing that this move only serves to exclude learners from gaining access to science, engineering, technology and accounting where shortages are always felt. Considering the historical inequities in the education system, students who choose mathematical literacy often come from poor family backgrounds and poor quality schools. We argue further that these pupils are often encouraged to take mathematical literacy to ensure that these schools attain a better pass rate, regardless of the quality of such pass rates. It does appear therefore, that the introduction of maths literacy is a case of taking three steps backwards when dealing with issues of producing enough quality students and graduates who can take their rightful place in scarce fields. In terms of addressing equity and social participation in the economic development of the country, this step may also be viewed as regressive.

Lastly, we raise questions about the growing tendency to blame the lack of guidance and counselling for students who are entering tertiary education as the main contributor to the current problem of a mismatch between the shortages of skilled people in certain categories and an oversupply in others. We raised two caveats on this matter: first, guidance and counselling has little impact on subject choice, if such a choice is encouraged at an early stage at school level, as is the case in South Africa. Second, guidance and counselling which should provide students with information about jobs that are likely to be needed without, at the same time, providing them with a probable supply in that profession is not going to make any difference. 


\section{Reference}

Blaug, M. (1976). Introduction to economics of education. London: Penguin.

Bombach, G. (1964). Comments on the paper by Messrs Tin Bergen and Bros. In The residual

factor and economic growth, ed. J. Vaizey. Paris: Organisation of Economic Community Development.

Carter, CF. (1965). Can we get higher education cheaper? Manchester Society. December, Reprinted, In Economics of education 2, ed. M. Blaug 1969. London: Penguin.

Daniels, RC. (2007). Skills shortages in South Africa. Literature Review. The Development Policy Research. Cape Town: University of Cape Town.

Department of Education: Education Statistics in South Africa 2000, 2001, 2002, 2003, 2004, 2005, 2006, 2007, 2008, 2009, www.education.gov.za.pdf (accessed 13 May 2011).

Department of Education, (2001). The National Plan on higher education. Pretoria: Department of Education.

Department of Higher Education and Training, (2010). Framework for the national skills development strategy. 2011/12 - 2015/16. First draft for consultation, 29 April 2010. Pretoria: Department of Higher Education and Training.

Du Plessis, JP. (2009). Nzimande calls on business to provide information on new graduates. http://www.ewn.co.zal articleprog. aspx?id=18250.pdf (accessed 15 July 2011).

Du Toit, R. (2005). Labour market and social policy. A Review of labour markets in South Africa. Career guidance and employment service. Pretoria: Human Sciences Research Council.

Du Toit, R \& Roodt, J. (2009). Engineering in developing countries. The profession and education of engineering professions in South Africa. Cape Town: Human Sciences Research Council.

Griesel, H \& Parker, B. (2009). A baseline study on South African graduates from the perspective of employers. Higher Education South Africa \& the South African Qualifications Authority. Pretoria: HESA.

Grobbelaar, R. (2011). Nzimande tells of skills plans. The Times 6 May 2011, 6.

Harvey, L. (2000). An employability performance indicator? Perspectives, 4 (4):105-109.

Hodgson, J. (2012). Big decline in no. of 2011 matric maths pass. Equal Education. www.politicsweb.co.za.results (accessed January 2012).

Jawitz, J. Case, J \& Tshabalala, M. (2000). Why not engineering? The process of career choice among South African female students. Journal of Engineering Education. 16 (6):40-47.

Jolly, AR. (1964). Education. In the economic and social revolution, ed. D. Seers. North Carolina: North Carolina University Press.

Lawless, A. (2005). Numbers and needs: Addressing imbalances in the civil engineering profession. Halfway House: South African Institute of Civil Engineering.

Mabena, P. (2000). Development of black chartered accountants: progress report.

Tema, Winter: 1-7.

Mlambo-Ngcuka, P. (2006). Address delivered at the Third Annual Julius Nyerere Memorial Lecture, at the University of the Western Cape, 06 September 2006. www.info.gov.za/speeches/2006/06090712151002.htm (accessed 11 December 2011).

Moleke, P. (2003). First Employment of Graduates. Pretoria: HSRC.

Motshekga, E. (2010). Report on the national Senior Certificate examination results 2010. Pretoria: Department of Basic Education.

Motshekga, E. (2012). Class of 2011 achieve $70.2 \%$ pass rate. www.education.gov.za/linlClickaspx?link=689\&tabid=36 (accessed 13 January 2012).

Nzimande, B. (2010). SA aims for more graduates, artisans. South Africa Information. http://www.southafrica.info/about/education/skills041110.htm (accessed 1 July 2011).

Organisation of Economic Community Development (OECD) (1996). Employment and growth in the knowledge-based economy. Paris: OECD.

Sadler, E. undated. Aspects of higher education and black chartered accountants: empirical findings. Department of Applied Accountancy. Pretoria: University of South Africa: www.unisa.ac.za/contents/faculties/ems/docs/es-paper.pdf. (accessed 13 September 2011).

Serrao, A. Gifford, G \& Flanagan, L. (2010). Motshekga gets F in maths. IOL news, 8 January 2010, 1.

Solidarity Research Institute, (2010). South Africa Transformation Monitor. (SA Monitor). Transformation in the education sector: enrolment in primary, secondary and tertiary education institutions and throughput and success of the school education system. www.solidarityresearch. co.za.pdf (accessed 20 July 2011).

South African Institute for Chartered Accountants (SAICA), (2008. The financial management, accounting and auditing skills shortage research report 2008. Executive summary. Pretoria: Tshwane University of Technology.

South Africa Institute of Race Relations (SAIRR). South Africa Surveys, 200910. Melville: SAIRR.

Woolard, I., Kneebone, P \& Lee, D. (2003). Forecasting the demand for scarce skills, 2001 - 2006. In Human Resources Development Review 2003: Education, employment and skills in South Africa. Cape Town: HSRC Press.

Yorke, M. (2006). Learning and employability: employability in higher education: what it is - what it is not. New York: The Higher Education Academy. http://www.heacademy.ac.uk/assets/documents/tla/employability/id116_employability_in_higher_education _336.pdf (accessed 11 December 2011). 